This item was submitted to Loughborough's Research Repository by the author.

Items in Figshare are protected by copyright, with all rights reserved, unless otherwise indicated.

\title{
Bounded entrepreneurial vitality: the mixed embeddedness of female entrepreneurship
}

PLEASE CITE THE PUBLISHED VERSION

http://dx.doi.org/10.1111/ecge.12092

PUBLISHER

(c) Wiley

VERSION

AM (Accepted Manuscript)

\section{PUBLISHER STATEMENT}

This work is made available according to the conditions of the Creative Commons Attribution-NonCommercialNoDerivatives 4.0 International (CC BY-NC-ND 4.0) licence. Full details of this licence are available at: https://creativecommons.org/licenses/by-nc-nd/4.0/

\section{LICENCE}

CC BY-NC-ND 4.0

\section{REPOSITORY RECORD}

Langevang, Thilde, Katherine Gough, Paul W.K. Yankson, George Owusu, and R. Osei. 2015. "Bounded Entrepreneurial Vitality: The Mixed Embeddedness of Female Entrepreneurship". Loughborough University. https://hdl.handle.net/2134/17830. 
Accepted for publication in Economic Geography. Issue and year not known.

Bounded Entrepreneurial Vitality: The Mixed Embeddedness of Female Entrepreneurship

\section{Thilde Langevang}

Department of Intercultural Communication and Management, Centre for Business and Development Studies

Copenhagen Business School

Porcelænshaven 18A, 2000 Frederiksberg C

Denmark

tl.ikl@cbs.dk

\section{Katherine V. Gough}

Department of Geography

Loughborough University

Loughborough LE11 3TU

United Kingdom

k.v.gough@lboro.ac.uk

\section{Paul W. K. Yankson}

Department of Geography and Resource Development

University of Ghana

P.O. Box LG 59 Legon

Ghana

pyankson@ug.edu.gh

\section{George Owusu}

Department of Geography and Resource Development

University of Ghana

$$
\text { EG_Gough } 1
$$


P.O. Box LG 59 Legon

Ghana

gowusu@ug.edu.gh

\title{
Robert Osei
}

Institute of Statistical, Social and Economic Research

University of Ghana

P.O Box LG 74, Legon

Ghana

rdosei@isser.edu.gh

\section{Key words:}

Women, entrepreneurs, female entrepreneurship, GEM, Ghana

\begin{abstract}
Despite the recent increased interest in female entrepreneurs, attention has tended to focus on dynamic individuals and generic incentives without considering the roles of gender and place in entrepreneurship. In this article, we draw on the notion of mixed embeddedness to explore how timeand-place-specific institutional contexts influence women's entrepreneurship. Drawing on primary data collected in Ghana, where exceptionally more women engage in entrepreneurial activities than men, we examine the scale and characteristics of female entrepreneurial activity, exploring the factors that account for this strong participation of women, and examine whether this high entrepreneurial rate is also reflected in their performance and growth aspirations. The findings reveal a disjuncture between, on the one hand, the vibrant entrepreneurial endeavors of Ghanaian women and positive societal attitudes toward female entrepreneurship and, on the other hand, female business activities characterized by vulnerability and relatively low achievement. The article shows how regulatory, normative, and cultural-cognitive institutional forces, which have been transformed over time by local and global processes and their interaction, are concomitantly propelling and impeding women's entrepreneurial activities. We propose that the study of female entrepreneurs within economic geography could be advanced by analyzing the differing effects of the complex, multiple, and shifting layers of institutional contexts in which they are embedded.
\end{abstract}




\section{Introduction}

Promoting female entrepreneurship has become a key policy focus throughout the Global South since it is believed that this will create employment, improve household welfare, and reduce poverty (Minniti and Naudé 2010; Spring 2009; Eversole 2004). This trend coincides with an increasing interest in private sector development and entrepreneurship in development debates (Minniti and Naudé 2010; Naudé, 2011; Langevang, Namatovu, and Dawa 2012; United Nations Development Programme 2004; Africa Commission 2009), and a growing recognition of women's contribution to economic growth through their business activities. Whereas female economic activities have tended in the past to remain relatively invisible, unrecorded, and disregarded as marginal, informal, and survivalist in nature, there is now a growing recognition of the importance of women's economic roles. Although the field of women's entrepreneurship has been dominated by experiences from the Global North, discussions from the Global South have also started to emerge (Gailey and Datta 2012; Minniti and Naudé 2010; Amine and Staub 2009; Eversole 2004; Hays-Mitchell 1999) long after Boserup’s (1970) pioneering work on women's contribution to development. Despite this mounting interest, economic geography has largely neglected the role of gender in entrepreneurship worldwide (though see Hanson 2009; Hanson and Blake 2009; Hays-Mitchell 1999).

This increased recognition of women's contribution to the economy has been accompanied by a focus on the gender-specific barriers that entrepreneurs face. While academics and policy makers agree that female entrepreneurs can be catalysts for growth and development, existing data on gender differences in rates of entrepreneurship show a marked difference in business start-ups between men and women in most countries (Kelley et al. 2011a). According to the Global Entrepreneurship Monitor $(\mathrm{GEM}){ }^{1}{ }$ there is a considerable gender gap in entrepreneurial activity worldwide, with significantly more men than women being in the process of starting a business or operating new businesses (Kelley et al. 2011a; Minniti 2010). Moreover, women’s businesses tend to be concentrated in certain sectors and show poorer performance; they are generally smaller and have fewer employees, exhibit slower sales growth, have lower growth ambitions, and show limited internationalization (Hanson 2009; Kelley et al. 2011a). Indeed, this may be one reason for the relative neglect of female entrepreneurship within economic geography, which has tended to focus on formal larger-scale, technological-oriented enterprises (Hanson 2009). This article seeks to remedy this lacuna with reference to the 2010 GEM survey results in Ghana, the only participating country in which the level of women's entrepreneurial activity exceeded that of men.

We examine the scale and characteristics of female Ghanaian entrepreneurial activity, seeking to explain why it is so distinctively high and analyze whether this is reflected in better performance and higher growth ambitions of female entrepreneurs. We demonstrate the need to disaggregate women's entrepreneurial activities and show the merits of adopting a mixed embeddedness perspective, which relates the scale and performance of female entrepreneurs to differing and shifting institutional contexts. This framework has the advantage of capturing the context-specific economic, political, social, cultural, and cognitive influences on women's entrepreneurship as well as the changing, differing, and sometimes contradictory effects of these. This article thus responds to recent calls for economic geographers "to attune our gaze to a range of actors and practices, drawing attention to the

\footnotetext{
${ }^{1}$ GEM is the largest survey of entrepreneurial activity in the world. In 2010 a total of 59 countries participated. For further details see http://www.gemconsortium.org/.
} 
intersection of economic, cultural, social, and institutional factors, to describe the changing shape of the global economy” (Clare and Siemiatycki 2014, 7).

We start by reviewing the existing literature on female entrepreneurship before highlighting links to embeddedness and institutional approaches. The focus then turns to Ghana where, after outlining the methodology, we explore the nature of female entrepreneurial vitality. A discussion of the limits to female entrepreneurship leads into a discussion of the mixed embeddedness of female entrepreneurship.

\section{Perspectives on Female Entrepreneurship}

Entrepreneurship is a contested concept that is defined in numerous ways. It started out as the domain of economists who examined entrepreneurship as a function of the economy. The most prominent writer on the topic, Joseph Schumpeter, described the entrepreneur as a hero figure who introduces groundbreaking innovations to the market (1934). Other important economists include Knight (1921) who focused on the entrepreneur as a risk taker, while Kirzner (1978) considered an entrepreneur to be somebody alert to profitable opportunities. In all these approaches, the entrepreneur was portrayed as being male, and the male pronoun was often used in relation to entrepreneurs (Ahl 2006). During the 1970s and 1980s, research on entrepreneurship became dominated by the personality trait approach. This focused on understanding the particular personality traits of entrepreneurs with the aim of developing an ideal personality profile of the successful entrepreneur. These studies included discussions of female entrepreneurs and how they differ from their male counterparts (Minniti and Naudé 2010). There is now widespread consensus that personality trait theory alone cannot account for the multiplicity of factors that influence decisions to become entrepreneurs. Increasingly entrepreneurship research is focusing on the ways in which external environmental factors, in combination with personality factors, influence gender differences in entrepreneurial activities (Amine and Staub 2009).

From the 1990s onward, research on female entrepreneurship became increasingly inspired by various strands of feminist theory (Greer and Green 2003). Liberal feminist theory started from the assumption that since men and women are essentially the same they are equally free to progress in life based on their talent and skills; women's lesser achievements are considered to be due to institutional barriers. The Marxist feminist approach, by contrast, sees women's domestic labor as productive, yet unpaid, work that is considered to be a key reason for the relative disadvantaged economic position of women. Studies from around the world have demonstrated that women still do the majority of housework and child care, which affects their labor market activities. Furthermore, male domination and the class system of economic domination are viewed as leading to the subordination of women in the labor market and women's unrecognized and unpaid domestic labor (Greer and Green 2003). The social constructionist/poststructuralist approach considers gender (as a social construct) to reflect upbringing and social interaction, which varies over time and between places; gender is not seen as something that is, but rather something that is done, accomplished or performed (Ahl 2006). This perspective has criticized much research on female entrepreneurship for attributing shortcomings of female entrepreneurs to individual characteristics and overlooking social, cultural, political, and institutional aspects that can affect male and female entrepreneurs in differing ways (Ahl 2006). Recently there have been widespread calls for greater consideration of the heterogeneity of female 
entrepreneurs and the implications of the differing contexts within which they are embedded (Ahl 2006; Brush, de Bruin, and Welter 2009; Hughes et al. 2012). With the increased emphasis on the context of entrepreneurship, geographers have the potential to play a more prominent role in the debate.

Feminist economic geographers have criticized the tendency to silence accounts of women's work and have analyzed the ways that gender and work are socially constructed at different scales and in diverse geographic contexts (Hanson 2009; McDowell 1999; Hanson and Pratt 1995; Oberhauser 2002). The prime focus of feminist economic geography, however, has been on women's experiences in the workplace and their position in the workforce, generally, with few studies focusing on female entrepreneurs or entrepreneurship as a gendered process (though exceptions include Hanson 2003, 2009; Hanson and Blake 2009; Mandel 2004; Hays-Mitchell 1999). In the late 1990s, Gunnerud (1997) argued that research on entrepreneurship within the field of economic geography was characterized by gender blindness with a focus on male-owned enterprises and male entrepreneurs. In an article published in this journal on women and entrepreneurship more than a decade later, Hanson (2009, 247) could still claim that there is an "absence of any gendered analysis of entrepreneurship in economic geography." Entrepreneurship research by economic geographers has tended to be limited to a subset of entrepreneurial activities focusing on those that are associated with technological innovation and export economies, while neglecting informal microbusinesses, hence tending to overlook many female entrepreneurial activities.

To move the research agenda on gender and entrepreneurship forward, Hanson $(2009,251)$ proposed a more inclusive definition of entrepreneurship arguing that entrepreneurship should be viewed as a "gendered geographic process." This inclusive definition of entrepreneurship, she claimed, should be expanded from the narrow focus on the (male) Schumpeteran hero figure who produces entirely new products or services, which cause disequilibrium in the market, to include anyone who "owns a business, assumes the risks associated with ownership, deals with the uncertainties of coordinating resources, and is in charge of day-to-day management of the business" (Hanson 2009, 251, drawing on Gartner 1989 and Light and Rosenstein 1995). Consequently there is no need to distinguish between "true entrepreneurship and mere self-employment" (Hanson 2003, 11), which is especially important in the Global South where much self-employment is informal. In the context of sub-Saharan Africa, Spring and McDade $(1998,28)$ similarly recommend a broad definition of entrepreneurship where "Entrepreneurs range from the woman in an open-air market selling dried beans and earning sixty-one cents a day to the M.B.A.-schooled manager of a large firm that has revenues of millions of dollars annually." Building on these discussions we consider an entrepreneur to be coincident with owning and managing a business including any self-employment or trade activity.

Although the literature on female entrepreneurship has been relatively limited in scope, there has long been a gendered perspective to discussions of the informal economy. In particular there has been considerable debate regarding whether women's increased participation in the informal economy contributes to their empowerment or to their impoverishment (Meagher 2010; Overå 2007). Economists who adhere to a free market approach have tended to perceive self-employment in the informal economy as offering women opportunities for social and economic empowerment, and argue for the need to remove legal and cultural barriers to increase women's participation in the informal economy. Critical feminists and political-economists critique this approach for neglecting the dynamics governing how the opportunities and constraints for women's economic empowerment operate, arguing rather that the informal economy is "a poverty trap for women, concentrating them in low-skill, low- 
income activities with little prospects of advancement” (Meagher 2010, 472).

Whilst recognizing that African feminism embraces diverse perspectives (Lewis 2001), a recurrent theme in this literature is that African women have had to struggle against both oppressive features of their own societies and against the imposition of Western norms since the days of colonial rule (Kikooma 2012; Mikell 1997). There is a tendency, though, in existing studies of female employment and entrepreneurship in Africa to group all women together overlooking differences between places, generations, and sectors (Spring 2009). To capture the gendered dynamics of entrepreneurship at different scales in particular places, we now turn to present a framework based on the notion of mixed embeddedness in multiple and changing institutional contexts.

\section{Female Entrepreneurship, Mixed Embeddedness and Institutions}

Embeddedness and institutionalist perspectives have become increasingly popular within economic geography, paralleling the growing emphasis placed on the social nature of economic actions and their manifestation in space (Hess 2004; Bathelt and Glückler 2014). The idea of social embeddedness was first deployed by Karl Polanyi to denote that the economy is enmeshed in institutions, economic as well as noneconomic. Polanyi argued that in nonmarket societies, economic activities are embedded in noneconomic kinship, religious, and political institutions, whereas in market societies, economic activities have been rationalized and economic actions have become disembedded from society (Polanyi 1944). The concept was subsequently revisited by Granovetter (1985), who argued that economic activities are embedded in social networks and relationships even in market societies. In view of the plethora of meanings and definitions of embeddedness that have since emerged, Pike, Lagendijk, and Vale (2000) and Hess (2004) have called for clearer and more consistent use of the term, urging scholars to make clear who is embedded in what"

In this article, we focus on female entrepreneurs and examine the effects of the multiple layers of institutional contexts in which they are embedded. To capture the interplay between political, economic, social, and cultural contexts we find it opportune to draw on the notion of mixed embeddedness. Mixed embeddedness was originally developed in relation to immigrant entrepreneurs to draw attention to the range of informal and formal institutional contexts in which these entrepreneurs are embedded (Kloosterman 2010; Kloosterman and Rath 2001). Adopting this notion in a study of graduate entrepreneurs in a rapidly changing environment in Tanzania, Mwasalwiba, Dahles, and Wakkee (2012, 396) propose that social embeddedness does not simply strengthen or weaken entrepreneurship, but that it implies "complex, partly converging and partly conflicting institutional forces at work which at the same time advance and impede entrepreneurial activities.” While the concept of mixed embeddedness was originally developed to capture the differing effects of immigrants' embeddedness in multiple societal contexts, the concept is also apt at grasping how female entrepreneurial activity is influenced by women's embeddedness in multiple and shifting institutional contexts, which may have contradictory effects (Welter and Smallbone 2010). Drawing on this perspective, entrepreneurs and the opportunity structures they act within can be seen as social phenomena embedded in social relations and differing institutional contexts, which operate at a range of scales (Mwasalwiba et al. 2012; Langevang et al. 2012).

Institutional perspectives view economic action as being shaped, enabled, and constrained by 
both formal and informal institutions (Pike et al. 2000; Bathelt and Glückler 2014). Of particular interest to economic geographers is how institutional contexts are spatially structured at interrelated scales and comprise a number of interlinked economic, social, political, cultural, and cognitive dimensions (Pike et al. 2000). Although Bathelt and Glückler (2014) indicate the need to elaborate on the nature of institutions, they do not scrutinize their gendered aspects. Institutional approaches that focus on the ways in which the social, political, and economic systems that entrepreneurs are embedded in grant them legitimacy have become increasingly popular in analyzing entrepreneurship in the Global South (Bruton, Ahlstrom, and Li 2010; Amine and Staub 2009; Welter and Smallbone 2010). Institutions set the rules of the game and define the available means of appropriate actions (North 1990). Underlying institutional theory is the concept of legitimacy, which refers to the perception that the actions of an entity are desirable, proper, or appropriate. To capture the different dimensions of institutions, we draw on institutional theory as developed by Scott (2001) who highlights three different levels of embeddedness in which economic processes take place: regulatory, normative, and cultural-cognitive.

Regulatory institutions refer to the legally enforced aspects of institutions and include policies, procedures, rules, and laws; they set the formal political and economic boundaries for action, in this case entrepreneurship (Welter and Smallbone 2010). Features of the regulatory system that affect entrepreneurship include the laws, regulations, and policies that support or constrain the creation of new businesses, reduce or increase risk for business owners, and facilitate or constrain access to resources. In this vein, feminist research has highlighted the key role that various state institutions play in forging gender relations and gendering work through the endorsement or marginalization of specific male and female roles (Radcliffe 1999; Laurie 1999). While female and male entrepreneurs may be affected equally by some rules and regulations, others are clearly gender specific, such as labor market rules giving equal access to employment positions, family policies, such as child care provision, and property rights allowing for female ownership of land (Amine and Staub, 2009; Welter and Smallbone, 2010). Importantly, regulatory systems for labor markets do not only work at the national level but include the "“command and control structures' of employment” at the global scale (Elson, 1999, 617).

Normative institutions denote more informal institutions and include both values and norms. While some values and norms apply to all members of a society, others are applicable only to certain actors. This gives rise to the notion of "roles," which are "conceptions of appropriate goals and activities for particular individuals or specified social positions" (Scott, 2001, 55). While normative institutions are often seen as constraining behavior, they can also empower and enable action. Taking these ideas to the field of entrepreneurship, it can be argued that female entrepreneurial activity in a society is related to normative perceptions of the appropriate roles for women. In many societies, an entrepreneur is seen as being bold, aggressive, calculating and risk taking - traits that are typically associated with males; such masculine stereotyping can restrain women from pursuing business ownership (Baughn, Chua, and Neupert, 2006). Furthermore, since women tend to be primarily defined through roles associated with the household, the construction of proper motherhood and good childrearing practices can negatively affect female participation in entrepreneurship. Amine and Staub (2009), for example, report how in sub-Saharan Africa a man whose wife works outside the home may be viewed as being unable to control her or provide adequately for his family; hence, many men refuse to allow their wives to run a business. In the context of the United States, Hanson (2003) recounted how female entrepreneurs are considered oppositional, contesting cultural norms, and subverting 
traditional gender ideologies that associate femininity with incompetence, weakness, and dependence on men; hence, for women who do start their own businesses, gender norms continue to be influential. And in Peru, Hays-Mitchell (1999) showed how despite women being key income earners, they are persistently constructed as housewives and mothers by the state, and male opposition to female entrepreneurs persists.

The cultural-cognitive dimension of institutions is "the shared conceptions that constitute the nature of social reality and the frames through which meaning is made” (Scott 2001, 57). Cognitive structures reflect scripts, schemas, and taken-for-granted knowledge that influence people in particular social settings. Within the field of entrepreneurship, cognitive embeddedness reflects the extent to which individuals believe that they have the skills and competencies to start/run businesses and the risk or fear they associate with entrepreneurship (Baughn et al., 2006; Amine and Staub, 2009). This influences the strategies and actions individuals take when starting and developing businesses (Welter and Smallbone, 2010).

Although, as highlighted here, institutions have various dimensions and operate at different scales, they are closely interlinked and can be both enabling and limiting, Existing research, however, has almost exclusively focused on the ways institutions (regulatory, normative, and cognitive) constrain female entrepreneurship. We make an important contribution to the literature, in this article, by revealing a more complex picture showing how institutions concomitantly act as constraining and enabling forces for female entrepreneurs. By drawing on the concept of mixed embeddedness we show that women in Ghana are enmeshed in a range of institutional contexts with differing impacts on their entrepreneurial activity.

\section{Researching Entrepreneurship in Ghana}

In this article, we draw on quantitative primary data supplemented with quantitative and qualitative secondary data. The main data source is the GEM survey, which was supervised and conducted by the authors in Ghana in 2010. This was the first time that Ghana participated in GEM and it was the only West African participant, although within sub-Saharan Africa Angola, Uganda, Zambia, and South Africa were also represented. Based on the most recent World Economic Forum’s Global Competitiveness Report, GEM divides participating countries into three levels: factor-driven, efficiency-driven, and innovation-driven (Kelley, Bosma, and Amorós 2011b). ${ }^{2}$ Ghana is classified as a factor-driven economy along with the other sub-Saharan African countries with the exception of South Africa, which is designated as an efficiency-driven economy.

A common methodology is adopted by all countries participating in GEM. The main data source is the Adult Population Survey (APS), which assesses entrepreneurial behavior and attitudes toward entrepreneurship among the general population. To ensure consistency and cross-country comparability, each participating country conducts the same questionnaire survey of its adult

\footnotetext{
${ }^{2}$ According to this classification, factor-driven economies are dominated by subsistence agriculture and extraction businesses, and rely mostly on labor and natural resources. Efficiency-driven economies are dominated by industrialization and an increased reliance on economies of scale, and capital-intensive larger businesses are more dominant. In innovationdriven economies businesses are increasingly knowledge intensive and have an expanding service sector.
} 
population (18-64 years old) with a minimum of 2,000 randomly selected individuals. In Ghana, 2,400 individuals were interviewed in 160 enumeration areas within 44 districts spread across all 10 regions. We trained teams of experienced research assistants who then carried out the interviews face to face under our supervision.

GEM adopts a broad conceptualization of entrepreneurship and defines an entrepreneur as an individual who is in the process of starting a business or is the owner-manager of a business. Compared to other enterprise surveys, it has the advantage of capturing both formally registered and informal businesses. The APS questionnaire is structured into a number of sections based on a distinction between four types of actors: potential entrepreneurs, nascent entrepreneurs, new business owner-managers, and established business owners (see Figure 1). The motivation for starting a business, the type of business activity, the degree of innovativeness and competitiveness, and growth expectations of early-stage and established business owners are recorded as well as the characteristics of social environments conducive to entrepreneurship. Nonbusiness owners are asked about their entrepreneurial intentions, and all respondents are asked about their attitudes toward entrepreneurship. Basic demographic characteristics of the respondents (education, age, household income, employment status) are also recorded. Depending on the activities of the respondent the questionnaire takes from five to 35 minutes to conduct.

[INSERT FIGURE 1 about here]

Although there are some limitations associated with using a standard questionnaire designed in a Global North context (see Gough, Langevang, and Namatovu 2014), the GEM data provide the possibility for the first time to examine overall patterns of female entrepreneurship in Ghana. In order

to place the characteristics of female entrepreneurs in Ghana in a broader context, we draw on the 2010 Global Entrepreneurship Women's Report, which examined women's entrepreneurial attitudes, activities, and aspirations across all the GEM participating countries (Kelley et al. 2011a). In looking for explanations of the patterns observed, we draw on existing qualitative studies of Ghanaian female entrepreneurs, some of which have been conducted by the authors who all have long-standing knowledge of Ghana.

\section{Female Entrepreneurial Vitality in Ghana}

In this section we turn to examine the nature of female entrepreneurship in Ghana, looking at the level of entrepreneurship, women's motives for engaging in entrepreneurship, and their attitudes toward entrepreneurship. We then turn to analyze the institutional roots of female entrepreneurship and show how socioeconomic change is transforming female entrepreneurship.

\section{Level of Entrepreneurship}

A central measure of GEM is the Total Early Stage Entrepreneurial Activity (TEA), which 
measures the proportion of the population that are nascent entrepreneurs or new business ownermanagers (see Figure 1). Ghana had a TEA of 33.9 percent in 2010, indicating that just over a third of the adult population was in the process of starting a business or was the owner-manager of an enterprise under three and one-half years old. Overall, Ghana had the third highest TEA, after Bolivia and Vanuatu, slightly higher than Zambia (32.6 percent), Angola (32.4 percent), and Uganda (31.3 percent), and considerably higher than South Africa (8.9 percent) (Kelley et al. 2011b).

Women's participation in entrepreneurial activity as measured by TEA ranges from just 1.5 percent of all women in Japan to 45.4 percent in Vanuatu (see Figure 2). Overall, factor-driven economies have a higher prevalence of female entrepreneurs than efficiency- or innovation-driven, confirming other research that shows that female rates of entrepreneurship tend to be higher in the Global South than Global North (Minniti and Naudé 2010). At all levels of economic development, there are more male than female entrepreneurs with the exception of Ghana, where a higher percentage of the female (37.1 percent) than male (30.7 percent) population are entrepreneurs. Consequently, just over half (55.1 percent) of entrepreneurs in Ghana are female.

[INSERT FIGURE 2] about here]

\section{Motivations for Entrepreneurship}

In order to examine why people start a business, GEM divides entrepreneurial motivation into two categories: opportunity entrepreneurs, who are viewed as being pulled into entrepreneurship based on a perceived opportunity, and necessity entrepreneurs, who enter entrepreneurship due to need (unemployment and poverty) and the lack of other opportunities. Although the necessity/opportunity bifurcation masks a multitude of motivations and their changing nature over time (Rosa, Kodithuwakku, and Balunywa 2006; Odom and Williams 2012; Langevang, Namatovu and Dawa 2012), it is still a widely used distinction that is useful to examine in a Ghanaian context.

Among Ghana’s nascent and new (TEA) entrepreneurs, 36.9 percent are classified as necessity entrepreneurs while 61.8 percent are opportunity entrepreneurs. Notably more women (44.6 percent) than men (27.4 percent), however, are motivated by necessity, and conversely more males than females are motivated by opportunity (see Figure 3). These findings correspond well with the argument that women in the Global South "face higher barriers to entry in the formal labor market and have to resort to entrepreneurship as a way out of unemployment and, often, out of poverty" (Minniti and Naudé 2010, 279). Numerous studies have shown how female entrepreneurship in the Global South tends to be concentrated in the informal economy (e.g., Hays-Mitchell 1999; Meagher 1995). In a Ghanaian context, as Overå (2007) has argued, women are overrepresented in the informal economy partly due to having greater difficulties than men accessing formal sector jobs. It is important to recognize though that more than half of the female entrepreneurs perceive themselves as opportunity driven, as explored below, due to historically rooted regulatory, normative, and cultural influences.

[INSERT FIGURE 3 about here] 


\section{Attitudes Toward Entrepreneurship}

In order to analyze the climate for entrepreneurship, GEM has two key measures: (1) attitudes toward entrepreneurship such as whether entrepreneurship is seen as a desirable career choice and the status attributed to entrepreneurs, and (2) the perceived capabilities of potential entrepreneurs such as the belief in having the knowledge and skills to start a business, perceived opportunities and the fear of failure. These measures can be seen as indicative of normative and cultural-cognitive institutions.

In Ghana, the high level of entrepreneurial activity among the population is matched by very positive societal views of entrepreneurship, higher than the norm at all three economic development levels (see Table 1). ${ }^{3}$ Nine out of ten Ghanaians (both business owners and nonbusiness owners) view entrepreneurship as a good career choice and accord high status to successful entrepreneurs. There are no marked differences in the views of men and women regarding their perceptions of entrepreneurship as a good career choice nor in the status they ascribe to entrepreneurs.

\section{[INSERT TABLE 1 about here]}

In terms of embarking on entrepreneurship, Ghanaians are more optimistic than even the population of most factor-driven economies, with just over three-quarters (75.7 percent) seeing good opportunities to start a firm in their area (see Table 2). ${ }^{4}$ Ghanaian women, however, are notably less likely (68.7 percent) than Ghanaian men (80.7 percent) to see themselves as being capable of starting a business. This is in line with the findings from other GEM-participating countries where women compared with men are equally likely to see entrepreneurship as attractive but are less confident in their own personal capacities to start a business (Kelley et al. 2011a). Nevertheless, of those not currently involved in any entrepreneurial activity, slightly more women than men intend setting up a business (67.5 percent compared with 66.2 percent, respectively), highlighting the necessity aspect of many female businesses. Despite this slight gender difference, the most striking picture that emerges of entrepreneurial intentions is the extremely high rates in Ghana - two-thirds of Ghanaians intend setting up a business_-far higher than the average for even factor-driven economies.

[INSERT TABLE 2 about here]

\footnotetext{
${ }^{3}$ The respondents' attitudes toward entrepreneurship are based on their answers to three questions: "In your country, do most people consider starting a new business a desirable career choice?" "In your country, do those successful at starting a new business have a high level of status and respect?" "In your country, do you often see stories in the public media about successful new businesses?”

${ }^{4}$ The respondents' perceptions of opportunities, her/his own capabilities, and intentions are based on answers to the following questions: "In the next six months, will there be good opportunities for starting a business in the area where you live?" "Do you have the knowledge, skills, and experiences required to start a new business?" "Are you, alone or with others, expecting to start a new business, including any type of self-employment, within the next three years?”
} 
Interestingly, fear of business failure among Ghanaians was the lowest of all GEM countries with slightly fewer women (10.1 percent) than men (11 percent) fearing business failure (see Figure 4 ). This suggests that fear of failure is not holding back potential entrepreneurs in Ghana, either male or female, who perceive an opportunity for starting a business.

[INSERT FIGURE 4 about here]

Having drawn on GEM data to establish an overview of the levels, motives, and attitudes toward entrepreneurship in Ghana, we now turn to examine the historic roots of female entrepreneurship and the various institutional factors that account for the high proclivity for women to start businesses, the high rates of both necessity and opportunity entrepreneurship, and the positive attitudes toward female entrepreneurs.

\section{Roots of Female Entrepreneurship}

Markets have historically played a key role in West Africa. By the late fifteenth century, when Europeans arrived at the coast of what is now known as Ghana, long-distance trade in fish and salt was well established, and by the beginning of the seventeenth century, local and regional trade in Ghana was flourishing (Chamlee-Wright 1997). The development of this indigenous entrepreneurship relied on "the evolution of cultural traditions and institutions which facilitated the extension of trade" (Chamlee-Wright 1997, 103). All the major ethnic groups in southern Ghana (including the Akan, Ga, and Ewe) developed regulatory institutions including a legal order, property rights structures as well as religious practices, leadership forms, and kinship structures that fostered commerce and promoted trade. Efficient methods of conflict resolution in marketplaces in Ghana are also considered to have facilitated trade (Chamlee-Wright 1997).

As in other West African countries, market trading in Ghana has long been regarded as women's work, with records dating back to 1602 describing women's central role in trade in Ghana (Overå 2007). The British colonial system established in 1874 focused on extracting and exporting natural resources out of the Gold Coast into Britain and importing products made in Britain to the Gold Coast. The corresponding structural changes in the economy, reinforced by gendered education policies, further entrenched the role of women in trade (Clark 1994; Overå 2007). Since primarily young men attended school, office jobs in the colonial administration became male dominated, and British firms exporting palm oil, rubber, and minerals generally employed men (Overå 2007). Furthermore, apart from the seamstress vocation, training in skilled trades was only offered to men, leaving women as the dominant actors in market trading (Chamlee-Wright 1997). Some aspects of colonialism discouraged women's participation in business and trade such as Christian teachings that focused on women's domestic roles. However, since trading corresponded to colonialist capitalist interests and was seen as a culturally legitimate way for women to earn money, market trading was reinforced as a female domain (Chamlee-Wright 1997; Overå 2007). Since the Gold Coast emerged as the world's major producer of 
cocoa in the 1990s, the increasing amount of money circulating in Ghana and the expanding urban population enhanced women's opportunities for trade. With gradual improvements in infrastructure, women also started to engage in long-distance trade to neighboring African countries (Overå 2007). Hence, these predominantly regulatory institutional factors laid the foundation for gendered occupations, with women dominating trade whereas men dominated formal sector jobs.

A key normative institution that has shaped the high level of entrepreneurial activity among women in Ghana is the cultural construction of gender roles in the home and motherhood. Women's and men's economic responsibilities within the household have long been separate but complementary, with expectations of what each should contribute to the household clearly defined (Robertson 1984). Women were traditionally considered to be responsible for providing the carbohydrate component of food and men the protein component. Although the exact division of responsibilities can vary between different ethnic groups and between urban and rural areas, over time it has evolved so that women are expected to provide a large part of the household's daily living expenses while men are expected to pay school fees and rent (Darkwah 2007a). Consequently, women’s roles as mothers have actually motivated them to set up businesses in order to secure an independent income and enable them to take good care of their children. As Clark $(2000,719)$ argued, child rearing and income-generating activities go hand in hand and are not seen as contradictory in the Akan ideal of womanhood: "The good, selfsacrificing Asante mother does not stay at home with her children, but goes out working hard for them.” Similarly Darkwah (2007a, 206) asserted that "The financial responsibilities of a mother toward her child take emotional precedence over the physical care of a child so that the very idea of a stay-athome mother seems ridiculous in the Ghanaian context." Although this evolving construction of gender roles leaves many everyday expenses in the hands of women, their increased economic responsibilities have simultaneously provided them a relatively high degree of autonomy and financial independence. Since women are able to travel freely and invest and manage their money as they like, this contributes to high levels of female entrepreneurship, which forms a key aspect of women's identities (Chamlee-Wright 1997; Wrigley-Asante 2013; Dzisi 2008).

This brief overview has illustrated how female entrepreneurs in Ghana have long been accorded high legitimacy facilitated by regulatory, normative, and cultural-cognitive institutions. As we show in the next section, this construction of female identity being compatible with business ownership, which has evolved over centuries, has deepened in recent decades, linked to economic restructuring and structural adjustment programs (SAPs).

\section{Socioeconomic Change and Female Entrepreneurship}

As feminist economic geographers have argued, globalization processes including SAPs "are historically and culturally contingent and engage with people in places to generate diverse and contradictory outcomes” (Nagar et al. 2002, 263). In many sub-Saharan African countries, the introduction of SAPs resulted in women becoming entrepreneurs for the first time. In Uganda, for example, which has relatively high levels of female entrepreneurship (see Figure 2), women were not historically economically active; rather they were dominant in subsistence agriculture, a role reinforced by colonial rule. Hence, female entrepreneurship in Uganda is a relatively new phenomenon born out of war, crisis, and structural adjustment during the 1970s and 1980s. Although, as highlighted above, women in Ghana were heavily engaged in income-generating activities prior to structural adjustment, 
economic crisis and the associated SAPs introduced during the 1980s acted as a further impetus to expand women's involvement in trade (Overå 2007).

The SAPs involved massive cuts in social services, retrenchment of public sector workers, removal of state subsidies, adjustment in the exchange rate through devaluation of Ghana's currency, abolishing domestic price controls, and the liberalization of trade (Konadu-Agyemang 2000). During structural adjustment, 60,000 civil servants were laid off. Although women only made up 25 percent of civil servants, 35 percent of those retrenched were female since employees with the least education and seniority were the first to lose their jobs (Overå 2007). Moreover, hundreds of thousands of workers in the formal private sector were laid off, the majority of whom were male. Hence, economic restructuring led to rising prices, increasing unemployment and underemployment, declining real incomes, and a growing need for cash to meet user charges for service provision. These economic changes, in combination with the cultural legitimacy of female entrepreneurial activities, resulted in female income-generating activities becoming more indispensable to family survival than ever and an increasing number of women establishing and expanding their businesses, primarily in trade (Owusu and Lund 2004; Robertson 1995). Hence, the prime effect of structural adjustment for women in Ghana was not so much that women started to work outside of the home, but rather that their existing breadwinner roles were reinforced since they could rely less on support from their husbands.

While SAPs resulted in a rise in necessity entrepreneurship among women, it concomitantly generated new opportunities for certain segments of female entrepreneurs. The trade liberalization policies made importing goods easier since the procedures for importing were made less cumbersome. This fostered a remarkable rise in the number of businesswomen engaged in the trade of global consumer goods (Darkwah 2007b). As Wrigley-Asante (2013, 321) argued, women’s cross-border trading now exists at a wide range of scales in Ghana "from carrying individual head-loads at border towns, to travelling by road within the Economic Commission of West African States (ECOWAS), to travelling by air to the United Kingdom, the United States of America, and newer trading areas such as China and the United Arab Emirates." Hence, in contrast to societies where cultural norms result in women's spatial range of business activities being more limited than men's, in Ghana as a consequence of the interlinked regulatory, normative, and cultural-cognitive dimensions of institutions, women are highly active in cross-border trading. Studies from other West African countries have similarly shown a link between high mobility and female entrepreneurial vitality; in Benin, for example, female entrepreneurs often engage in cross-border trade, and their ability to traverse space is a key factor in their entrepreneurial activities (Mandel 2004).

The proclivity for women to start a business in Ghana has expanded into the twenty-first century with the continuation of neoliberal economic reform programs emphasizing free trade and private enterprise as key to national growth and development. New opportunities, for example, have emerged in another female dominated activity - hairdressing - which has boomed in response to globalization and trade liberalization promoting new styles and permitting the importation of new products (Langevang and Gough 2012). High and sustained growth rates, ${ }^{5}$ together with increasing urbanization,

\footnotetext{
${ }^{5}$ During the last decade, Ghana has recorded growth rates averaging 5 percent per annum, and in 2010 an impressive growth rate of 7.7 percent was recorded (Institute of Statistical, Social and Economic Research 2011). While data on the size of the informal economy are notoriously unreliable, it is widely accepted that between 80 and 90 percent of the population works in the informal sector in Ghana.
} 
an expanding middle class, and rising consumerism in the cities, are additional factors spurring opportunities for entrepreneurship (Mahajan 2009). Since Ghana's high growth rates are not being accompanied by formal sector employment creation, the vast majority of young women and men joining the workforce each year enter the informal sector where setting up a business of one's own is the preferred choice over working informally for others (Langevang and Gough 2012; Gough, Langevang, and Owusu 2013).

Female entrepreneurship in contemporary Ghana thus cuts across class and age categories, spanning young female street vendors operating in the informal economy to so-called businesswomen who are women of high social standing who have registered their businesses, have formal bank accounts - in some cases with a working capital of thousands of dollars-and many of whom travel across the globe (Darkwah 2007b). While elsewhere in Africa "women as successful entrepreneurs is widely regarded as illegitimate and unacceptable” (Amine and Staub 2009, 201 emphasis in original), in Ghana successful female entrepreneurs are widely respected (Darkwah 2007b). However, despite Ghana being home to many successful highly educated female entrepreneurs, most female entrepreneurial activity is still dominated by women who have limited formal education and are part of households with meager earnings.

These findings from Ghana contrast with much existing research from elsewhere, where entrepreneurship is considered a male endeavor and the roles of wife and mother are seen as incompatible with business ownership resulting in lower normative support for female entrepreneurship and impeding women's start-ups (Amine and Staub 2009; Baughn et al. 2006). As has been shown above, in Ghana female entrepreneurs are able to draw on the cultural legitimacy attached to entrepreneurship, which is embedded within regulatory, normative, and cultural-cognitive institutions.

\section{Limits to Female Entrepreneurship in Ghana}

In this section we explore the performance of female entrepreneurs, analyzing the sectors in which they participate, their growth aspirations, and rates of business failure to explore whether the high levels of entrepreneurship and institutional support to women's start-ups are also reflected in these measures.

\section{Sector Participation}

There are clear differences between the sectors that men and women in Ghana enter (see Table 3). The most common sectors for women are trading, followed by services, small-scale manufacturing, and agriculture. For men, their most prevalent activity is services followed by trading, agriculture, and small-scale manufacturing/processing. Within these sectors, occupations are highly gendered. For women, the dominant service occupations are hairdressing, catering, and restaurant ownership whereas for men they are commercial transport, electrician, auto mechanics, communication/ICT/photo lab services, entertainment centers, and bar ownership. In manufacturing, women dominate in dressmaking, bead making, and soap making whereas men engage primarily in metal fabrication, carpentry, and artisanal work. Men are involved in a wider range of occupations than women and a 
greater number of these are entirely male occupations; only a few activities, such as food vending, catering, and fish mongering, are the sole preserve of women. These findings correspond with studies from a range of different cultural settings that have highlighted a marked gendering of occupations (Lawson 1999; Hays-Mitchell 1999; McDowell 2009, 2013) and that women's businesses tend to be concentrated in retail and service sectors (Hanson 2003; Gough 2010).

[INSERT TABLE 3 about here]

Despite these marked gender differences, the GEM data indicate the transgressing of gender norms. Men are now found in many occupations that have traditionally been considered as female such as hairdressing, food processing, and trading. This confirms Overå's (2007) findings that the sociocultural boundaries that define male and female income-generating activities are being renegotiated as constraints and/or new opportunities arise. However, women are less able to break into male-dominated occupations indicating that "socio-cultural boundaries therefore appear to be narrower and less flexible when women attempt to enter male domains than vice versa" (Overå 2007, 559). The only domain women seem to have been able to keep almost entirely to themselves is the marketplace. This shows that the normative and cultural-cognitive dimensions of institutions are limiting the domains that women can enter. Contrary to findings elsewhere (Lawson 1999), this does not mean the sectors women dominate are less highly valued than male professions. Skills in Ghana are widely obtained through the apprenticeship system; although skills training is highly gendered (Langevang and Gough 2012), the trades women enter are perceived to be on an equal footing to those that men dominate. Women in Ghana find their businesses restricted due to the number of entrepreneurs engaging in similar activities, resulting in high levels of competition, not because their professions lack respect.

Due to this high concentration of women in a limited number of professions, there is a real need for them to be innovative in order to attract customers. The GEM data, however, report that male TEA entrepreneurs are much more innovative than their female counterparts-16.1 percent versus 9.4 percent. ${ }^{6}$ Even more surprisingly, Ghana's female entrepreneurs have the lowest levels of innovation in the GEM data set after Uganda (Kelley et al. 2011a). Consequently, women's businesses in Ghana appear to be constrained due to their lack of innovativeness. It is important, however, to recognize that the GEM data records entrepreneurs' own perceptions of their innovativeness. The cultural-cognitive dimension of institutions may result in women underreporting ways in which they are innovative. As Blake and Hanson (2005, 686) argued, "the social identities of innovators figure into the ways that institutions in particular contexts promote, value, and define innovations.”

\section{Business Performance, Growth Aspirations, and Failure}

The vast majority of nascent and new businesses in Ghana have fewer than five employees.

\footnotetext{
${ }^{6}$ Innovation levels are recorded as the extent to which an entrepreneur considers his/her products/services to be new to customers and whether other enterprises are offering the same product/service.
} 
Businesses operated by women are typically smaller than those operated by men, with around twothirds of female entrepreneurs having no employees compared to half of male entrepreneurs (see Table 4). Not only do female entrepreneurs have fewer employees than their male counterparts, they also expect to engage fewer employees in the future; just over a half of female TEA entrepreneurs do not expect to employ any workers compared to just less than a third of male TEA entrepreneurs (see Table 5). Slightly more men (45.1 percent) than women (41 percent) expect to employ one to five workers, considerably more men (16.7 percent) than women (4.7 percent) expect to engage six to 10 employees, though hardly any entrepreneurs expect to employ more than 10 workers. These figures tie in with global trends where growth aspirations for female entrepreneurs are generally lower than for men at all levels of economic development (Kelley et al. 2011a), ${ }^{7}$ reflecting institutional norms and expectations that large businesses are run by men as well as cultural-cognitive institutions that impact on women's behaviors and business strategies.

\section{[INSERT TABLES 4 and 5 ABOUT HERE]}

The GEM data show that although more Ghanaian women than men run nascent and new businesses, more men than women are established business owners, that is, owner-managers of businesses more than three and a half years old. ${ }^{8}$ This reflects the fact that female businesses in Ghana are closing down at a proportionately higher rate than male run businesses; the discontinuance rate for men is 31.6 percent whereas for women, it is 45.1 percent. This is similar to other factor-driven economies (with the exception of Zambia and Guatemala) where men also dominate established business ownership, indicating that women are less willing and/or able than men to continue operating their businesses after several years. It cannot be assumed, however, that because women close down a business, they stop being entrepreneurs. Studies from Ghana and elsewhere in sub-Saharan Africa have documented a high prevalence of pluri-activity, ${ }^{9}$ diversification and the practice of changing business activity to coincide with changing opportunities and constraints (Gough 2010; Langevang et al. 2012; Rosa et al. 2006).

Entrepreneurs close their businesses for a range of reasons. Among Ghanaian women, the most frequent reasons for discontinuing a business are problems of accessing finance, lack of profitability, and personal reasons (see Table 6). Men reported the same primary reasons but were notably less likely to stop due to difficulties accessing finance. Since women's businesses tend to be smaller, and due to their increased financial responsibilities in the home, women find it harder than men to plough money

\footnotetext{
${ }^{7}$ In order to capture growth aspirations, GEM asks entrepreneurs how many employees they have at the time of the survey and how many they expect to employ in five years' time. The difference signifies the growth expectation.

${ }^{8}$ An owner-manager of an established business is defined as somebody who owns and manages an operating business that has paid salaries, wages, or any other payments to the owners for more than 42 months. Established business ownership is based on the following question: "Are you, alone or with others, currently the owner of a business you help manage, selfemployed, or selling any goods or services to others?” If the respondent answers yes, she/he is then asked how long the founder has received "wages, profits, or payment in kind from this business."

${ }^{9}$ Individuals who report both nascent and new business ownership activity are only counted once in the TEA. Individuals who report nascent or new business ownership in addition to established ownership are counted in the TEA as well as in the figure for established business ownership.
} 
back into their businesses to keep them running. Moreover, the smaller size of their business and their limited collateral make it harder for women to access finance from formal institutions. This regulatory discrimination is also reported elsewhere in sub-Saharan Africa where only a quarter of applicants were successful in obtaining a loan, with firm size being a determining factor (Amine and Staub, 2009).

[INSERT TABLE 6 about here]

The GEM data show that while women have high entrepreneurial rates, they also have high rates of business closure and show poorer business performance. These findings highlight the discrepancy between, on the one hand, the vibrant entrepreneurial endeavors of Ghanaian women and an institutional framework that generates positive attitudes toward female entrepreneurship and, on the other hand, the relative vulnerability, low achievement, and ephemeral existence of their entrepreneurial pursuits. We now turn to analyze how the mixed embeddedness of women's entrepreneurship in multiple, complex, overlapping, and contradictory institutional contexts works to propel and impede their entrepreneurial activities concurrently.

\section{Mixed Embeddedness of Female Entrepreneurship}

Key to understanding the high entrepreneurial rate of women in Ghana is the high degree of legitimacy surrounding female traders, which has been facilitated by the regulatory, normative, and cultural-cognitive institutional context. A combination of economic, political, social, and cultural factors has encouraged and enabled women to become entrepreneurs. Historically, the regulatory institutional environment expedited women's trade by hindering their access to formal wage employment and facilitating trade in first agricultural goods and later global consumer goods. Consequently, women came to dominate trade in Ghana at all scales, from local to global. Closely connected to the regulatory framework, the normative and cultural dimensions of the institutional environment cast women as able business owners. Crucially, business ownership is viewed as compatible with marriage and motherhood; being a wife/mother and being highly mobile engaging in long-distance trade is not seen as counteracting gender norms and ideologies. While the businesses that women can establish are influenced by the types of occupation deemed suitable for women and gendered skills training through the apprenticeship system, women's businesses are not generally any less respected than men's. Women are generally considered capable entrepreneurs, and their ability to contribute financially to the household economy through their businesses is highly valued; indeed it is expected.

These same institutions, however, concomitantly act as constraining forces for women's entrepreneurship, especially women's ability to expand their businesses. Increased expectations that women should contribute to household finances places an extra burden on women as the roles of entrepreneur and breadwinner have not led to a concurrent demise in women's roles as wives and mothers. Similar to situations found elsewhere in both the Global North and South, women often retain major responsibility for the home and family life, reinforcing a complex balancing act between the competing demands of paid work and unpaid household work (McDowell 1999; Smith et al. 2011). 
Cooking, which can be very time consuming in Ghana, is still considered a woman's responsibility and, especially in rural areas, women have the additional burden of fetching water and fuel. While becoming a mother compels many Ghanaian women to start a business in order to secure the future of their children, looking after small children restricts their entrepreneurial pursuits. Consequently, women often chose to work from home or bring the children along while working (Gough 2010). As Overå (2007) showed, having children does not impact much on men's working hours or working practices whereas women, unless they can afford day care or are able to get help from relatives, have the extra burden of taking care of their children.

The practice of women contributing to their husband's income-generating activities further limits the time they can spend on their own business. Consequently, women have less time to work on their own farms and businesses or explore alternative markets for their produce (Amu 2004). Lacking time and resources means that women have less time to become involved in networking activities that are key to ensuring new sources of finance, new customers and markets, and gaining new knowledge and information (Amine and Staub 2009). Hence, women are less likely to be innovative or expand their businesses, and they have higher failure rates.

While women have been juggling household and business activities for centuries, a consequence of recent neoliberal economic policies combined with changing gender norms is that men are increasingly unable or unwilling to contribute their share of household budgets and are entering women's entrepreneurial domains. As this results in "a double burden of increasing expenses and diminishing incomes for women” (Overå 2007, 553), women have to spend a larger part of their profits on household expenditures and therefore have less money to reinvest in their businesses. Furthermore, while men are now able to transgress gender norms and enter vocations that have previously been viewed as female domains, women are still concentrated in a few overpopulated activities. Hence, as Darkwah (2007b) also argued, the neoliberal ideology that has underlined Ghana's development policies for the last three decades has had contradictory implications for female entrepreneurs. It has propelled business ownership and created new opportunities while at the same time increasing competition and eroding support structures.

\section{Conclusion}

This article has shown how Ghanaian women have an exceptionally high rate of participation in entrepreneurial activity outnumbering males. This unusual situation of female dominance in entrepreneurship derives from women's' embeddedness in diverse institutional contexts that are historically and locally grounded yet are undergoing continual change. Paradoxically, while a range of local and global forces have stimulated women's participation in entrepreneurial activities, the same forces limit the scope and longevity of these businesses. As in many other countries in the Global South, Ghanaian women are more likely to enter entrepreneurship out of necessity, are found in a limited number of occupations, show less growth ambition, higher closure rates, and have a lower degree of innovation than their male counterparts.

These findings underline the importance of contextualized understandings of women's entrepreneurship and the significance of viewing entrepreneurial activity as a gendered process embedded in institutions that both drive and simultaneously impede women's entrepreneurial pursuits. 
We have shown how a framework built around the concept of mixed embeddedness and institutional theory facilitates grasping how female entrepreneurial activity is propelled and constrained by different regulatory, normative, and cultural-cognitive place-based institutional contexts. Women in Ghana, in contrast to the global norm, are widely cast as able entrepreneurs and breadwinners. Many are compelled to start businesses because of, and not despite, motherhood and are able to traverse space with their businesses. They are, nevertheless, restricted by the widespread perception that women are the prime caretakers of home and family, and they are constrained in sectors of the economy with high competition and meager earnings. The institutional environment surrounding female entrepreneurship becomes like a double-edged sword for women: they enjoy the legitimacy and freedom associated with female participation in entrepreneurship and are able to show drive and capacity in business activities, yet are simultaneously constrained in limited sectors of the economy and burdened by the double workload involved in concurrently being an entrepreneur and a homemaker.

These findings have important implications for both research and policy. As Minniti and Naudé (2010) noted, understanding the differences between individuals and across countries is key to understanding female entrepreneurship, its causes and effects, and its implications for policy. In particular, "the growing number of initiatives aimed at promoting entrepreneurship in developing countries, and particularly at empowering women in the process, should take such differences and commonalities into account” (Minniti and Naudé 2010, 278). As shown here, in a Ghanaian context, it is not female entrepreneurial activity as such that is in short supply and needs to be promoted; rather it is the institutional impediments to women's business survival and growth that need to be further scrutinized.

This article makes several important contributions to broader debates within economic geography. Aligned with Clare and Siemiatycki's (2014) call, the need to broaden our view of what counts as entrepreneurship to include a wider range of activities and actors including female business owners in the Global South has been illustrated. Furthermore, the article demonstrates the merits of using a framework built around the concept of mixed embeddedness and institutional theory to uncover interactions between cultural and political economic aspects of entrepreneurial activity and their differential and gendered effects. With the more global outlook of economic geography today, worldwide surveys like GEM that provide a standardized methodology, yet are flexible enough to capture local dynamics and sociocultural values/processes, when combined with qualitative insights, can help us to understand the variegated implications around the world of increasingly economic globalization.

\section{References}

Ahl, H. 2006. Why research on women entrepreneurs needs new directions. Entrepreneurship Theory and Practice 30:595-621.

Africa Commission. 2009. Realising the potential of Africa’s youth. Copenhagen, Denmark: Danish Ministry of Foreign Affairs. Available online: http://www.netpublikationer.dk/um/9336/pdf/realising_potential_africas_youth.pdf 
Amine, L. S., and Staub, K. M. 2009. Women entrepreneurs in sub-Saharan Africa: An institutional theory analysis from a social marketing point of view. Entrepreneurship and Regional Development 21:183-211.

Amu, N. J. 2004. The role of women in Ghana's economy. Available online: http://library.fes.de/pdffiles/bueros/ghana/02990.pdf.

Bathelt, H., and Glückler, J. 2014. Institutional change in economic geography. Progress in Human Geography 38:340-63.

Baughn, C. C., Chua, B.-L., and Neupert, K. E. 2006. The normative context for women's participation in entrepreneurship: A multicountry study. Entrepreneurship Theory and Practice 30:687-708.

Blake, M. K., and Hanson, S. 2005. Rethinking innovation: context and gender. Environment and Planning 37:681-701.

Boserup, E. 1970. Woman’s role in economic development. London: Earthscan.

Brush, C., de Bruin, A., and Welter, F. 2009. A gender-aware framework for women's entrepreneurship. International Journal of Gender and Entrepreneurship 1:8-24.

Bruton, G. D., Ahlstrom, D., and Li, H. L. 2010. Institutional theory and entrepreneurship: Where are we now and where do we need to move in the future. Entrepreneurship Theory and Practice 34:421-40.

Chamlee-Wright, E. 1997. The cultural foundations of economic development: Urban female entrepreneurship in Ghana. London: Routledge.

Clare, K., and Siemiatycki, E. 2014. Primacy or pluralism: Future directions in economic geography. Professional Geographer 66:4-10.

Clark, G. 1994. Onions are my husband. Survival and accumulation by West African market women. Chicago: University of Chicago Press. . 2000. Mothering, work, and gender in urban Asante ideology and practice. American Anthropologist 101:717-29.

Darkwah, A. K. 2007a. Work as a duty and as a joy: Understanding the role of work in the lives of Ghanaian female traders of global consumer items. In Women's labour in the global economy: Speaking in multiple voices, ed. S. Harley. 206-220. New Brunswick, NJ: Rutgers University Press.

. 2007b. Making hay while the sun shines: Ghanaian female traders and their insertion in the global economy. In The gender of globalization: Women navigating cultural and economic marginalities, ed. N. Gunewardena and A. Kingsolver, 61-83. Oxford: James Currey.

Dzisi, S. 2008. Entrepreneurial activities of indigenous African women: A case of Ghana. Journal of Enterprising Communities: People and Places in the Global Economy 2:254-64.

Elson, D. 1999. Labor markets as gendered institutions: Equality, efficiency and empowerment issues. World Development 27:611-27. 
Eversole, R. 2004. Change makers? Women’s microenterprises in a Bolivian city. Gender, Work and Organization 11:123-42.

Gailey, R., and Datta, P. B. 2012. Empowering women through social entrepreneurship: Case study of a women’s cooperative in India. Entrepreneurship Theory and Practice 36:569-87.

Gartner, W.B. 1989. "Who is an entrepreneur?” is the wrong question. Entrepreneurship Theory and Practice (summer): 47-68

Gough, K.V. 2010. Continuity and adaptability of home-based enterprises: A longitudinal study from Accra, Ghana. International Development Planning Review 32:45-70.

Gough, K. V., Langevang, T., and Namatovu, R. 2014. Researching entrepreneurship in low-income settlements : The strengths and challenges of participatory methods. Environment and Urbanization 26:297-311.

Gough, K. V., Langevang, T., and Owusu, G. 2013. Youth employment in a globalising world. International Development Planning Review 35:91-102.

Granovetter, M. 1985. Economic action and social structure: The problem of embeddedness. American Journal of Sociology 93:481-510.

Greer, M. J., and Green, P. G. 2003. Feminist theory and the study of entrepreneurship. In New perspectives on women entrepreneurs, ed. J. E. Butler, 1-24. Greenwich, CT: Information Age Publishing.

Gunnerud, N. 1997. Gender, place and entrepreneurship. Entrepreneurship and Regional Development: An International Journal 9:259-68.

Hanson, S. 2003. Geographical and feminist perspectives on entrepreneurship. Geographische Zeitschrift, 91:1-23. . 2009. Changing places through women’s entrepreneurship. Economic Geography 85:245-67.

Hanson, S., and Blake, M. 2009. Gender and entrepreneurial networks. Regional Studies 43:135-49.

Hanson, S., and Pratt, G. 1995. Gender, work, and space. New York: Routledge.

Hays-Mitchell, M. 1999. From survivor to entrepreneur: Gendered dimensions of microenterprise development in Peru. Environment and Planning A 31:251-71.

Hess, M. 2004. 'Spatial' relationships? Towards a reconceptualization of embeddedness. Progress in Human Geography 28:165-86.

Hughes, K. D., Jennings, J. E., Brush, C., and Welter, F. 2012. Extending women's entrepreneurship in new directions. Entrepreneurship Theory and Practice 36:429-42.

Institute of Statistical, Social and Economic Research. 2011. The state of the Ghanaian economy in 2010. Accra: Institute of Statistical, Social and Economic Research. 
Kelley, D. J. Brush, C. G., Greene P. G., and Litovsky, Y. 2011a. 2010 women’s report. Global entrepreneurship monitor. Available online: http://www.gemconsortium.org/docs/download/768.

Kelley, D. J., Bosma, N. and Amorós. J. E. 2011b. Global entrepreneurship monitor 2010 global report. Available online: http://www.gemconsortium.org/docs/download/266.

Kikooma, J. 2012. Gender and entrepreneurship in Uganda: Women manoeuvring economic space. In Entrepreneurship_Gender, geographies and social context, ed. T. Burger-Helmchen, 15-30. : Rijeka, Croatia: In Tech Open. Available online: http://cdn.intechopen.com/pdfswm/31887.pdf.

Kirzner, I. M. 1978. Competition and entrepreneurship. Chicago: University of Chicago Press.

Kloosterman, R. C. 2010. Matching opportunities with resources: A framework for analysing (migrant) entrepreneurship from a mixed embeddedness perspective. Entrepreneurship \& Regional Development: An International Journal 22:25-45.

Kloosterman, R., and Rath, J. 2001. Immigrant entrepreneurs in advanced economies: Mixed embeddedness further explored. Journal of Ethnic and Migration Studies 27:189-201.

Knight, F. H. 1921. Risk, uncertainty and profit. Boston: Houghton Mifflin Company.

Konadu-Agyemang, K. 2000. The best of times and the worst of times: Structural adjustment programs and uneven development in Africa: The case of Ghana. Professional Geographer 53:469-83.

Langevang, T., and Gough, K. V. 2012. Diverging pathways: Young female employment and entrepreneurship in Sub-Saharan Africa. Geographical Journal 178: 242-52.

Langevang, T., Namatovu, R. and Dawa, S. 2012. Beyond necessity and opportunity entrepreneurship: Motivations and aspirations of young entrepreneurs in Uganda. International Development Planning Review 34:339-60.

Laurie, N. 1999. State-backed work programmes and the regendering of work in Peru: Negotiating femininity in the 'provinces'. Environment and Planning A 31:229-50.

Lawson, V.1999. Tailoring is a profession, seamstressing is work! Revisiting work and reworking gender identities among artisanal garment workers in Quito. Environment and Planning A 31:209-27.

Lewis, D. 2001. African feminisms. Agenda 16:4-10.

Light, I. and Rosenstein, C. 1995. Expanding the interaction theory of entrepreneurship. In: The economic sociology of immigration: Essays on networks, ethnicity and entrepreneurship, ed. A. Portes, 166-212. New York: Russell Sage Foundation.

Mahajan, V. 2009. Africa rising. Upper Saddle River, NJ: Pearson Education.

Mandel, J. L. 2004. Mobility matters: Women's livelihood strategies in Porto Novo, Benin. Gender, Place \& Culture 11:257-87. 
McDowell, L.1999. Gender, identity and place: Understanding feminist geographies. Polity Press in association with Blackwell Publishers Ltd.

. 2009. Working bodies: Interactive service employment and workplace identities. Chichester, UK: Wiley-Blackwell.

. 2013. Working lives: Gender, migration and employment in Britain, 1945-2007. Chichester, UK: Wiley-Blackwell.

Meagher, K. 1995. Crisis, informalization and the urban informal sector in Sub-Saharan Africa, Development and Change 26:259-84.

. 2010. The empowerment trap: Gender, poverty and the informal economy in Sub-Saharan Africa. In The international handbook of gender and poverty: Concepts, ed. S. Chant, 472-77. Cheltenham, UK: Edward Elgar Publishing.

Mikell, G. ed. 1997. African feminism: The politics of survival in Sub-Saharan Africa. Philadelphia: University of Pennsylvania Press.

Minniti, M. 2010. Female entrepreneurship and economic activity. European Journal of Development Research 22:294-312.

Minniti, M., and Naudé, W. 2010. What do we know about the patterns and determinants of female entrepreneurship across countries? European Journal of Development Research 22:277-93.

Mwasalwiba, E., Dahles, H., and Wakkee, I. 2012. Graduate entrepreneurship in Tanzania: Contextual enablers and hindrances. European Journal of Scientific Research 76:386-402.

Nagar, R., Lawson, V., McDowell, L., and Hanson, S. 2002. Locating globalization: Feminist (re)readings of the subjects and spaces of globalization. Economic Geography 78:257-84.

Naudé, W. 2011. Entrepreneurship is not a binding constraint on growth and development in the poorest countries. World Development 39:33-44.

North, D. 1990. Institutions, institutional change and economic performance. Cambridge: Cambridge University Press.

Oberhauser, A. 2002. Feminism and economic geography: gendering work and working gender. In $A$ companion to economic geography, ed. E. Sheppard and T. J. Barnes, 60-76. Oxford: Blackwell.

Odom, K., and Williams, C. C. 2012. Evaluating the motives of informal Entrepreneurs in Koforidua, Ghana. Journal of Developmental Entrepreneurship 17:1-17.

Overå, R. (2007) When men do women’s work: structural adjustment, unemployment and changing gender relations in the informal economy of Accra, Ghana. Journal of Modern African Studies 45:539-63.

Owusu, G., and Lund, R. 2004. Markets and women’s trade: Exploring their role in district development in Ghana. Norwegian Journal of Geography 58:113-24. 
Pike, A., Lagendijk, A., and Vale, M. 2000. Critical reflections on 'embeddedness' in economic geography: Labour market governance in the North East region of England. In Restructuring industry and territory: the experience of Europe's regions, ed. A. Giunta, A. Lagendijk and A. Pike, 59-82. London: TSO.

Polanyi, K. 1944. The great transformation. The political and economic origins of our time. Boston: Beacon Press.

Radcliffe, S. A. 1999. Latina labour: Restructuring of work and renegotiations of gender relations in contemporary Latin America. Environment and Planning A 31:196-208.

Robertson, C. 1984. Sharing the same bowl: A socioeconomic history of women and class in Accra, Ghana. Bloomington: Indiana University Press.

. 1995. Comparative advantage: Women in trade in Accra, Ghana and Nairobi, Kenya. In African market women and economic power, ed. B. House-Midamba and K. E. Ekechi, 99-119. London: Greenwood Press.

Rosa, P. J., Kodithuwakku, S., and Balunywa, W. 2006. Entrepreneurial motivation in developing countries: what does "necessity" and "opportunity" entrepreneurship really mean? Frontiers of Entrepreneurship Research 26:1-14.

Schumpeter, J. A. 1983 [1934]. The theory of economic development. New Brunswick, NJ: Transaction.

Scott, W. R. 2001. Institutions and organizations. Thousand Oaks, CA: Sage.

Smith, F., Wainwright, E., Buckingham, S., and Marandet, E. 2011.Women, work-life balance and quality of life: Case studies from the United Kingdom and Republic of Ireland, Gender, Place \& Culture: A Journal of Feminist Geography 18:603-10.

Spring, A. 2009. African women in the entrepreneurial landscape: Reconsidering the formal and informal sectors. Journal of African Business 10:11-30.

Spring, A., and McDade, B. E. 1998. Entrepreneurship in Africa: Traditional and contemporary paradigms. In African entrepreneurship: Theory and reality, ed. A. Spring and B. E. McDade, 1-34. Gainsville: University Press of Florida.

United Nations Development Programme. 2004. Unleashing entrepreneurship: making markets work for the poor. Report of the Commission on the private sector and development. New York: United Nations Development Programme.

Wrigley-Asante, C. 2013. Survival or escaping poverty: The perspectives of poverty and well-being among Ghanaian women in cross-border trading. Journal of Gender Studies 22:320-34.

Welter, F., and Smallbone, S. 2010. The embeddedness of women's entrepreneurship in a transition context. In Women entrepreneurs and the global environment for growth, ed. C. G. Brush, A. de Bruin, E. J. Gatewood, and C. Henry, 96-116. Cheltenham, UK: Edward Elgar Publishing. 


\section{Table 1}

\section{Attitudes Toward Entrepreneurship}

\begin{tabular}{|lccc|}
\hline $\begin{array}{l}\text { Entrepreneurship as a good career choice } \\
\text { (percentage) }\end{array}$ & & & \\
\hline & Female & Male & Total \\
Ghana* & 90.4 & 91.8 & 91.1 \\
GEM average factor-driven economies & 75.8 & 74.8 & 75.3 \\
GEM average efficiency-driven economies & 73.2 & 72.5 & 72.9 \\
GEM average innovation driven-economies & 58.1 & 60.1 & 59.1 \\
\hline $\begin{array}{l}\text { High status to successful entrepreneurs } \\
\text { (percentage) }\end{array}$ & & & \\
\hline & Female & Male & Total \\
Ghana* & 90.4 & 91.2 & 90.8 \\
GEM average factor-driven economies & 80.6 & 81.2 & 80.9 \\
GEM average efficiency-driven economies & 70.2 & 69.4 & 69.8 \\
GEM average innovation driven economies & 70.5 & 70.1 & 70.3 \\
\hline $\begin{array}{l}\text { Media attention for entrepreneurship } \\
\text { (percentage) }\end{array}$ & & & \\
\hline & Female & Male & Total \\
\hline Ghana* & 75.3 & 81.6 & 78.5 \\
GEM average factor-driven economies & 66.2 & 64.6 & 65.4 \\
GEM average efficiency-driven economies & 63.3 & 61.6 & 62.5 \\
GEM average innovation driven economies & 54.7 & 55.9 & 55.3 \\
\hline
\end{tabular}

Sources: *GEM APS Survey Ghana 2010 and Kelley et al. (2011a). 


\section{Table 2}

\section{Attitudes of Potential Entrepreneurs}

\begin{tabular}{|c|c|c|c|}
\hline \multicolumn{4}{|l|}{ Perceived opportunities (percentage) } \\
\hline & Female & Male & Total \\
\hline Ghana* & 76.0 & 75.4 & 75.7 \\
\hline GEM average factor-driven economies & 58.9 & 64.2 & 61.6 \\
\hline GEM average efficiency-driven economies & 41.0 & 44.9 & 43.0 \\
\hline GEM average innovation-driven economies & 29.5 & 37.1 & 33.3 \\
\hline \multicolumn{4}{|l|}{ Perceived capabilities (percentage) } \\
\hline & Female & Male & Total \\
\hline Ghana* & 68.7 & 80.7 & 74.6 \\
\hline GEM average factor-driven economies & 64.6 & 77.5 & 71.1 \\
\hline GEM average efficiency-driven economies & 49.9 & 61.8 & 55.9 \\
\hline GEM average innovation-driven economies & 35.2 & 53.2 & 44.2 \\
\hline \multicolumn{4}{|c|}{$\begin{array}{l}\text { Entrepreneurial intentions (among people not involved in entrepreneurial activity } \\
\text { - percentage) }\end{array}$} \\
\hline & Female & Male & Total \\
\hline Ghana* & 67.5 & 66.2 & 66.8 \\
\hline GEM average factor-driven economies & 39.2 & 46.1 & 42.7 \\
\hline GEM average efficiency-driven economies & 19.9 & 27.1 & 23.5 \\
\hline GEM average innovation-driven economies & 6.0 & 10.5 & 8.3 \\
\hline
\end{tabular}

Sources: *GEM APS Survey Ghana 2010 and Kelley et al. (2011a).

\section{Table 3}

Distribution by Sector of Male and Female Entrepreneurs in Ghana

\begin{tabular}{|l|c|c|c|}
\hline \multicolumn{1}{|c|}{ Sector } & $\begin{array}{c}\text { Female } \\
\text { (percentage) }\end{array}$ & $\begin{array}{c}\text { Male } \\
\text { (percentage) }\end{array}$ & $\begin{array}{c}\text { Total } \\
\text { (percentage) }\end{array}$ \\
\hline Trading & 64.9 & 31.7 & 46.9 \\
\hline Services & 16.7 & 33.2 & 25.6 \\
\hline Processing/manufacturing & 12.6 & 15.4 & 14.1 \\
\hline Agriculture & 5.8 & 19.7 & 13.4 \\
\hline
\end{tabular}


Source: GEM APS Survey Ghana 2010.

\section{Table 4}

Number of Employees of Female and Male Nascent and New Business Owners in Ghana

\begin{tabular}{|l|c|c|c|}
\hline $\begin{array}{l}\text { Number of } \\
\text { Employees }\end{array}$ & $\begin{array}{c}\text { Female } \\
\text { Entrepreneurs } \\
\text { (percentage) }\end{array}$ & $\begin{array}{c}\text { Male } \\
\text { Entrepreneur } \\
\text { s } \\
\text { (percentage) }\end{array}$ & $\begin{array}{c}\text { Total } \\
\text { Entrepreneurs } \\
\text { (percentage) }\end{array}$ \\
\hline None & 67.0 & 50.0 & 59.8 \\
\hline 1 to 5 & 31.0 & 41.4 & 35.4 \\
\hline 6 to 10 & 1.5 & 5.6 & 3.2 \\
\hline 11 to 15 & 0 & 0.4 & 0.2 \\
\hline 16 to 20 & 0 & 2.1 & 0.9 \\
\hline $20+$ & 0.6 & 0.5 & 0.5 \\
\hline
\end{tabular}

Source: GEM APS Survey Ghana 2010.

Table 5

Job Growth Expectations for Nascent and New Business Owners in Ghana

\begin{tabular}{|l|c|c|c|}
\hline $\begin{array}{l}\text { Number of } \\
\text { Additional } \\
\text { Employees }\end{array}$ & $\begin{array}{c}\text { Female Entrepreneurs } \\
\text { (percentage) }\end{array}$ & $\begin{array}{c}\text { Male Entrepreneurs } \\
\text { (percentage) }\end{array}$ & $\begin{array}{c}\text { Total Entrepreneurs } \\
\text { (percentage) }\end{array}$ \\
\hline None & 52.4 & 31.6 & 43.0 \\
\hline 1 to 5 & 41.0 & 45.1 & 42.9 \\
\hline 6 to 10 & 4.7 & 16.7 & 10.1 \\
\hline 11 to 15 & 0.5 & 1.7 & 1.0 \\
\hline
\end{tabular}




\begin{tabular}{|l|l|l|l|}
\hline 16 to 20 & 0.7 & 2.0 & 1.3 \\
\hline $20+$ & 0.7 & 3.0 & 1.8 \\
\hline
\end{tabular}

Source: GEM APS Survey Ghana 2010.

Table 6

Reasons for Discontinuing Business by Gender in Ghana

\begin{tabular}{|l|c|c|c|}
\hline \multicolumn{1}{|c|}{$\begin{array}{c}\text { Reason for Business } \\
\text { Closure }\end{array}$} & $\begin{array}{c}\text { Female } \\
\text { Entrepreneurs } \\
\text { (percentage) }\end{array}$ & $\begin{array}{c}\text { Male Entrepreneurs } \\
\text { (percentage) }\end{array}$ & $\begin{array}{c}\text { Total Entrepreneurs } \\
\text { (percentage) }\end{array}$ \\
\hline Problems getting finance & 34 & 25 & 30.4 \\
\hline Business not profitable & 26.5 & 23.8 & 25.4 \\
\hline Personal reasons & 21.3 & 21.1 & 21.2 \\
\hline An incident & 8.6 & 13.3 & 4.4 \\
\hline $\begin{array}{l}\text { Another job or business } \\
\text { opportunity }\end{array}$ & 3.8 & 6.5 & 3.6 \\
\hline $\begin{array}{l}\text { Exit was planned in } \\
\text { advance }\end{array}$ & 3.1 & 4.4 & 0.3 \\
\hline $\begin{array}{l}\text { An opportunity to sell the } \\
\text { business }\end{array}$ & 0.3 & 0.4 & 1.0 \\
\hline Retirement & 0 & 2.7 & 2.6 \\
\hline Other & 2.5 & 2.8 & \\
\hline
\end{tabular}

Source: GEM APS Survey Ghana 2010. 


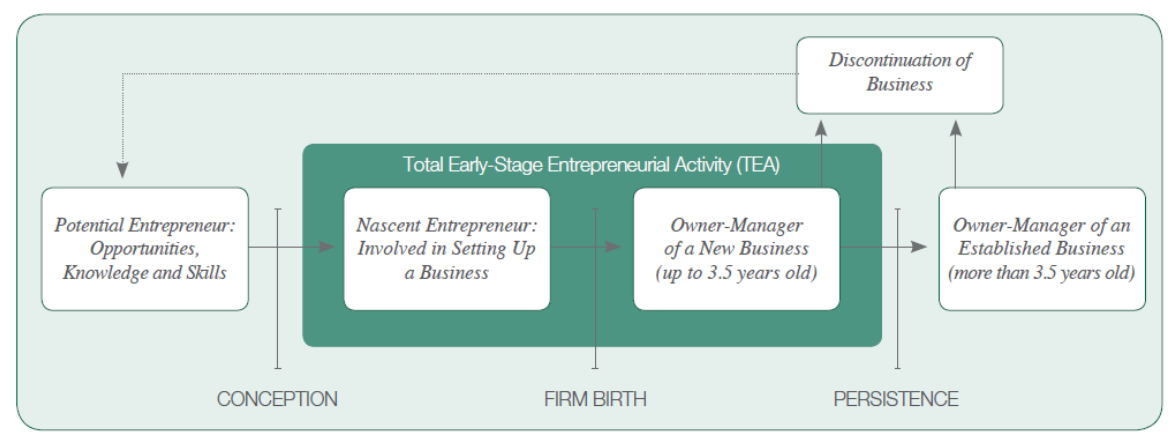

Figure 1. GEM operational definitions.

Source: Kelley et al., 2011b).

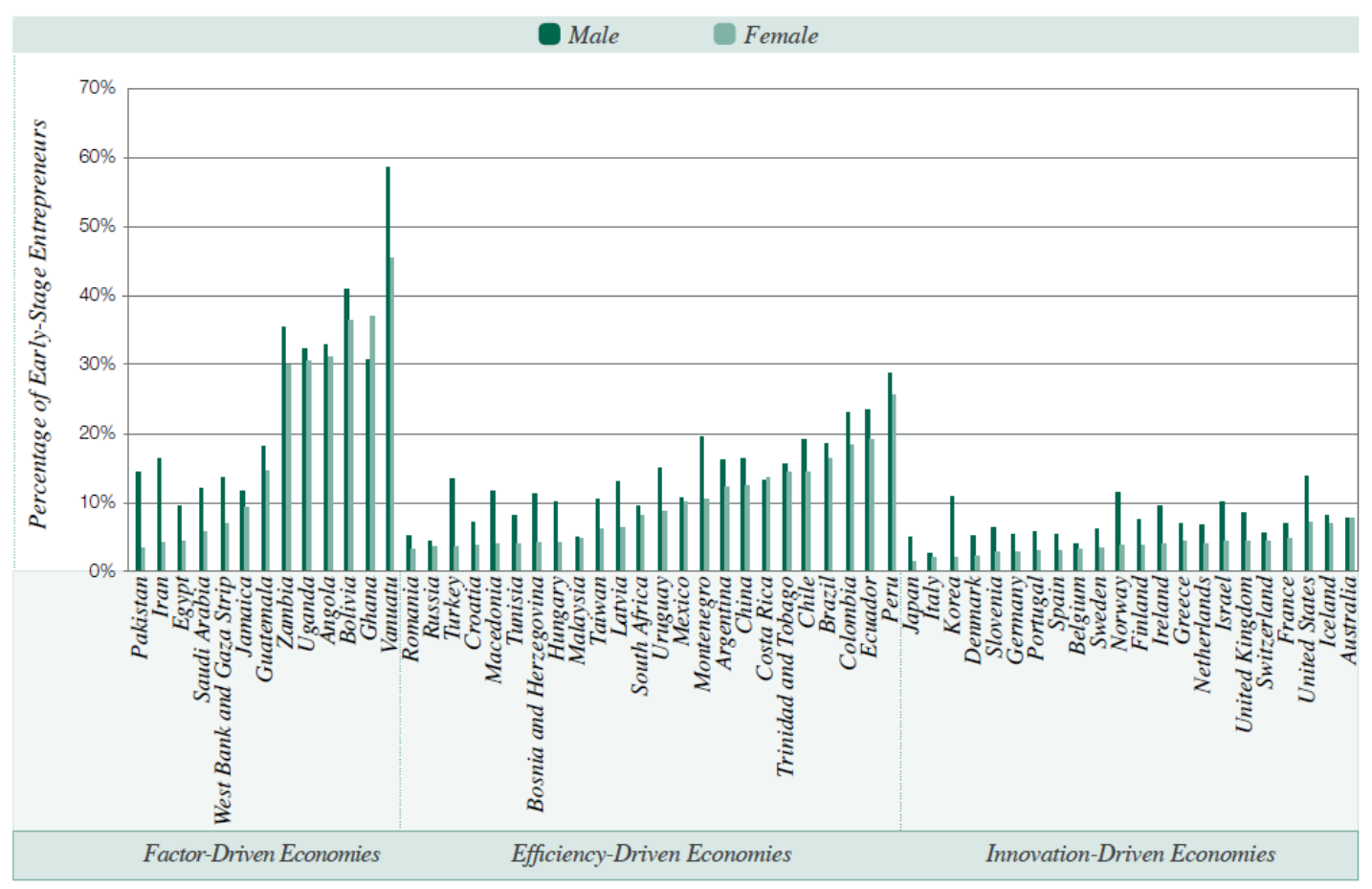

Source: GEM Adult Population Survey (APS) 
Figure 2. Proportion of the adult female and male population engaged in Total Early Stage Entrepreneurial Activity (TEA) in 59 economies, ranked within economic group by level of female participation (Kelley et al., $2011 b)$.

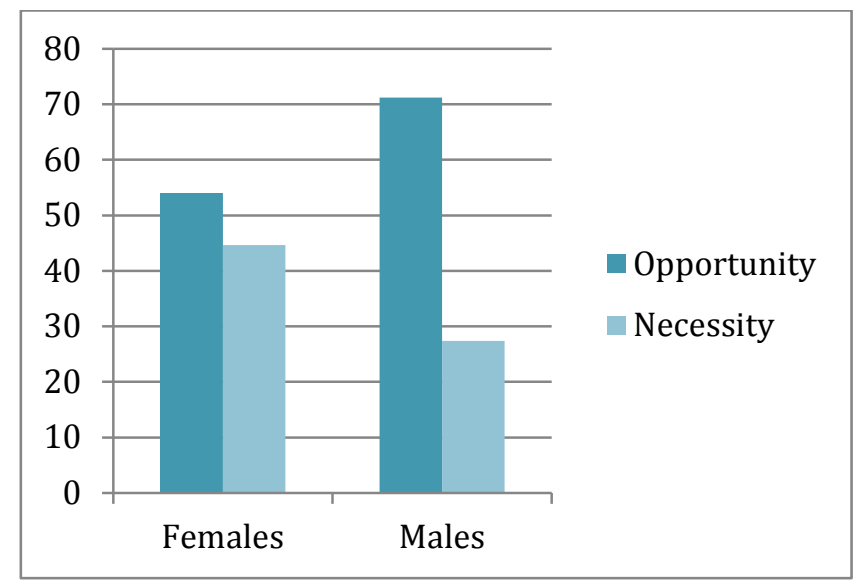

Figure 3. Percentage of male and female TEA entrepreneurs in Ghana who are necessity and opportunity driven.

Source: GEM APS Survey Ghana 2010.

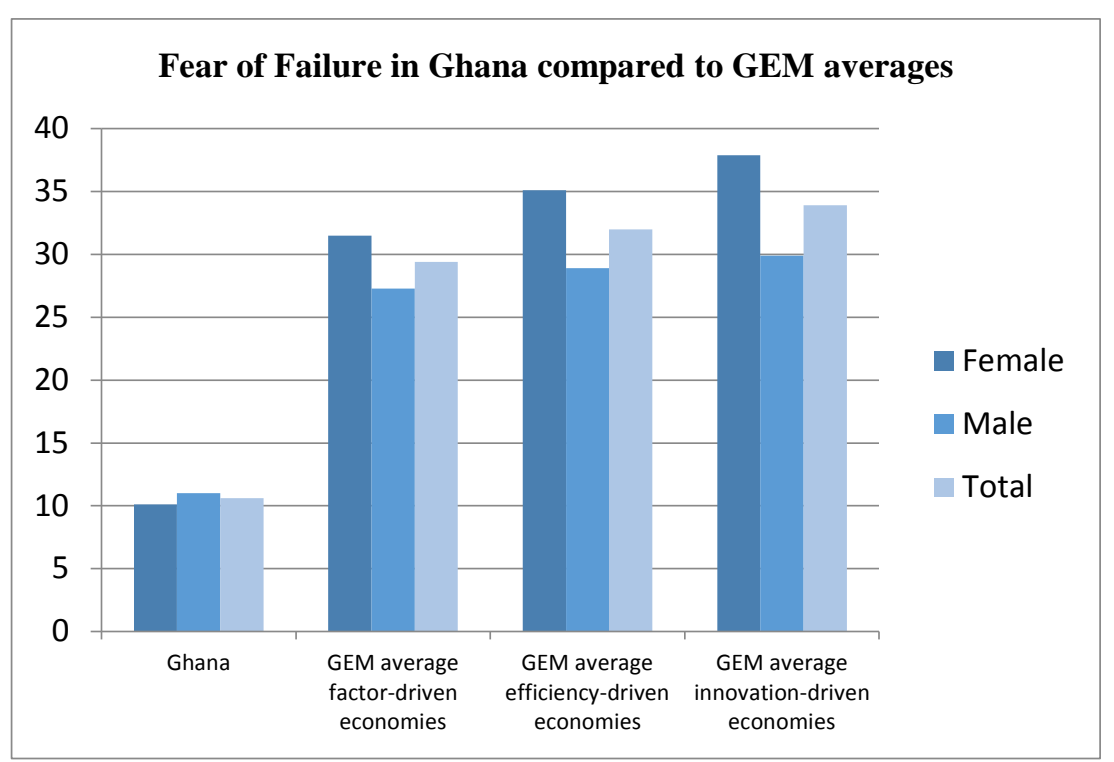

Figure 4. Fear of failure among individuals who perceive good opportunities.

Sources: GEM APS Survey Ghana 2010 and Kelley et al. (2011a)). 